CFaculty of Veterinary Medicine, Zagazig University, 44511, Egypt

DOI: $10.21608 /$ zvjz.2017.28669.

\title{
Biochemical Studies on Rosemary and Licorice against Lead -Induced Oxidative Stress in Rats
}

Mohamed A. Hashem ${ }^{1 *}$, Amany A. Abdallah ${ }^{1}$, Ibtisam G. Eldeen ${ }^{2}$ and Mahmoud M. Amer ${ }^{2}$

${ }^{1}$ Clinical Pathology Department, Faculty of Veterinary Medicine, Zagazig University, 44511,

Egypt

${ }^{2}$ Animal Health Research Institute, Zagazig branch, Egypt

\begin{abstract}
The present study was carried out to explore the effect of rosemary and licorice alone or in combination with lead acetate on the biochemical parameters of adult male albino rats. A120 rats were equally divided into 6 groups. Group1 was kept as a control group (negative control). Groups 2 and 3 received aqueous extract of rosemary (100 mg/kg BW/day) and licorice (150 $\mathrm{mg} / \mathrm{kg} \mathrm{BW} /$ day) alone, respectively. Group 4 was given lead acetate $(0.2 \%)$ alone; Group 5 was administrated lead acetate $(0.2 \%)$ in combination with the aqueous extract of rosemary and Group 6 received lead acetate $(0.2 \%)$ in combination with licorice. All treatments were given orally in drinking water for 6 weeks. Blood samples were collected at $2^{\text {nd }}, 4^{\text {th }}$ and $6^{\text {th }}$ weeks posttreatment. Results showed that chronic lead toxicity caused a significant disturbance in liver and kidney functions, as well as serum antioxidants and immunoglobulins. However, rosemary or licorice extracts restored such changes. This study revealed that lead exposure induced severe oxidative stress and disturbed simultaneously the serum biochemical profile of albino male rats and rosemary or licorice administration improved these disturbances.
\end{abstract}

Keywords: Liver enzymes, Rosemary, Licorice, Creatinine, Catalase.

\section{Introduction}

Oxidative stress is a natural activity occurring due to an imbalance between the antioxidants and production of free radicals. It is one of the most important problems affecting the animals causing serious problems affecting health and production [1]. Insufficient amounts of antioxidants or antioxidant enzymes result in oxidative stress that causes massive reactive oxygen containing molecules, severe inflammation and cell damage that affected the cell [2]. Antioxidants play role in the treatment of lead poisoning [3]. Lead toxicity encourages severe oxidative stress, which causes tissue damage to the exposed individuals [4]. It occurs due to continuous exposure to lead compounds through air, water and food.

Medicinal plants with antioxidant effects such as rosemary and licorice are excellent choice to protect against oxidative stress with least side effects. The antioxidant effect of rosemary (Rosmarinus officinalis L.) is due to its content of flavonoids and phenolic compounds [5]. Licorice (Glycyrrhiza glabra L.) has many biological and pharmacological effects, as antioxidant, immunoregulatory activities and atherosclerosis inhibition that attributed to its content of glycyrrhizin, triterpenoid saponin and various phenolics [6]. The protective role of rosemary and licorice extracts on lead acetate-induced oxidative stress is not entirely investigated. Thus, the current study was aimed to assess the antioxidant effect of rosemary and licorice on biochemical parameters of rats with oxidative stress or toxicity induced by lead.

\section{Material and methods \\ Preparation of plants extracts}

Rosemary aqueous extract: the air-dried leaves (obtained from Mansoura University garden in the winter) were coarsely powdered. The powder $(8 \mathrm{~g})$ were dissolved in $100 \mathrm{~mL}$ of distilled water then boiled for $5 \mathrm{~min}$ and infused for $10 \mathrm{~min}$. Subsequent to cooling and passing via the filter paper, a clear solution was acquired [7]. Licorice aqueous extract: the dipping method was used for extraction with $10 \mathrm{~g}$ of licorice powder (licorice roots were purchased from private market at Damietta) extracted with $500 \mathrm{~mL}$ ethanol/water (30:70, $\mathrm{v} / \mathrm{v})$. The powder of licorice was mixed, stirred and dipped for 50 minutes at $60{ }^{\circ} \mathrm{C}$ [8].

\section{Experimental design}


A total of 120 clinically healthy male albino rats weighing 200-250g were obtained from the Animal Laboratory House, Faculty of Veterinary Medicine, Zagazig University, Egypt. All animals were kept in clean metal cages under hygienic conditions and fed with balanced ration and provided with ad-libitum water. The ethical regulations for the protection of animals' welfare were in accordance with the guidelines of Faculty of Veterinary Medicine, Zagazig University, Egypt. The rats were randomly divided into six groups (each of 20). Group1 kept as control group (negative control). Group 2 received rosemary aqueous extract $(100 \mathrm{mg} / \mathrm{kg}$ BW/day) orally in drinking water for 6 weeks [9]. Group 3 received licorice aqueous extract $(150 \mathrm{mg} / \mathrm{kg} \mathrm{BW} /$ day $)$ orally in drinking water for 6 weeks [10]. Groups 4 (positive control) received lead acetate $2 \%(99.6 \%$ purity, purchased from El-Gomhoria Pharmaceutical Chemical Co. Zagazig, Egypt) in drinking water for 6 weeks [11]. Group 5 received lead acetate $2 \%$ in combination with the aqueous extract of rosemary, while group 6 received lead acetate $2 \%$ in combination with the licorice with the same dose, route and duration as previously mentioned. The rats were cautiously monitored during the study for signs of toxicity, morbidity and mortality. At the end of $2^{\text {nd }}, 4^{\text {th }}$ and $6^{\text {th }}$ weeks of the experiment, blood samples were collected from 5 rats of each group from the retro-orbital venous plexus into clean, dry and labeled centrifuge tubes without anticoagulant. The tubes were left to clot and serum was carefully separated after centrifugation at $3000 \mathrm{rpm}$ for 10 minutes for biochemical analysis.

\section{Biochemical analysis}

The obtained serum was used to assess serum markers of hepatic and renal disorders. Serum aminotransferases (AST [12] and ALT [13] and ALP activities [14] as well as total protein (TP) and albumin levels [15] were colorimetrically determined using kits (BioMérieux, Marcy l'etoile, France). The serum globulin level was estimated by subtracting the albumin from TP level [16]. Serum $\operatorname{IgG}$, IgM and $\operatorname{IgA}$ were determined using a radial immunodiffusion (RID) assay [17]. Serum levels of urea [18] and creatinine [19] were evaluated using colorimetric kinetic methods. Oxidative stress was assessed through estimating the enzymatic antioxidant biomarkers; i.e. CAT [20] and SOD [21]. Lipid peroxidation was evaluated by measuring MDA content in tissues [22].

\section{Statistical analysis}

Statistical analysis of the data was carried out using one-way analysis of variance (ANOVA) followed by Duncan's multiple range tests [23].

\section{Results \\ Clinical observations and mortality rate}

Rats in groups one, two and three appeared healthy without any clinical signs of illness or mortalities during the experimental periods. On the other hand, rats in group 4 showed ruffled coat and hairs, pale mucous membrane, weakness and the mortality rate was $25 \%$. Moreover, the clinical signs were reduced post treatment in groups 5 and 6 with mortality rate of $5 \%$ and $10 \%$, respectively.

\section{Serum biochemical parameters Effect on liver enzymes}

Rats in groups 2 and 3 showed a nonsignificant change in ALT, AST and ALP activities in all experimental periods when compared with the control group. On the other hand, groups 4, 5 and 6 showed a significant increase in serum ALT, AST, and ALP at the end of the $2^{\text {nd }}$ and $4^{\text {th }}$ week of the experiment. The highest values were detected in group 4. Non significant changes in serum enzymes of groups 5 and 6 were observed at the end of the $6^{\text {th }}$ week when compared with the control group. Rats in groups 5and 6 showed a significant decrease in ALT, AST and ALP in comparison to rats in group 4 in all the experimental periods. 
Table 1: Serum liver enzymes of albino rats at 2, 4 and 6 weeks post-treatment (Means \pm SE)

\begin{tabular}{|c|c|c|c|c|c|c|c|c|c|}
\hline \multirow{3}{*}{ Parameters } & \multicolumn{9}{|c|}{ Times post-treatment } \\
\hline & \multicolumn{3}{|c|}{2 weeks } & \multicolumn{3}{|c|}{4 weeks } & \multicolumn{3}{|c|}{6 weeks } \\
\hline & $\operatorname{ALT}(\mathbf{I U} / \mathbf{L})^{1}$ & $\operatorname{AST}(\mathrm{IU} / \mathrm{L})^{2}$ & $\operatorname{ALP}(\mathrm{IU} / \mathrm{L})^{3}$ & ALT (IU/L) & AST (IU/L) & $\mathbf{A L P}(\mathbf{I U} / \mathbf{L})$ & ALT (IU/L) & AST (IU/L) & ALP (IU/L) \\
\hline $\mathbf{G}_{1}$ & $26.12 \pm 0.24^{\mathrm{c}}$ & $41.26 \pm 0.44^{\mathrm{c}}$ & $151.30 \pm 0.54^{\mathrm{c}}$ & $26.00 \pm 0.35^{\mathrm{c}}$ & $41.00 \pm 0.71^{\mathrm{d}}$ & $150.00 \pm 0.71^{\mathrm{c}}$ & $25.16 \pm 0.41^{\mathrm{b}}$ & $43.00 \pm 0.52^{\mathrm{b}}$ & $149.00 \pm 1.22^{b}$ \\
\hline $\mathbf{G}_{\mathbf{2}}$ & $25.70 \pm 0.20^{\mathrm{c}}$ & $41.44 \pm 0.22^{c}$ & $153.74 \pm 0.31^{\mathrm{c}}$ & $26.40 \pm 0.54^{\mathrm{c}}$ & $44.02 \pm 0.51^{\mathrm{d}}$ & $152.70 \pm 1.18^{\mathrm{c}}$ & $25.60 \pm 0.36^{\mathrm{b}}$ & $42.98 \pm 0.38^{\mathrm{b}}$ & $151.10 \pm 0.72^{b}$ \\
\hline $\mathbf{G}_{\mathbf{3}}$ & $25.80 \pm 0.15^{\mathrm{c}}$ & $41.18 \pm 0.26^{\mathrm{c}}$ & $153.20 \pm 1.07^{\mathrm{c}}$ & $27.00 \pm 0.40^{\mathrm{c}}$ & $43.52 \pm 0.53^{\mathrm{d}}$ & $151.40 \pm 1.04^{\mathrm{c}}$ & $26.28 \pm 0.35^{\mathrm{b}}$ & $42.76 \pm 0.64^{b}$ & $151.48 \pm 0.97^{\mathrm{b}}$ \\
\hline $\mathbf{G}_{\mathbf{4}}$ & $43.60 \pm 1.36^{\mathrm{a}}$ & $86.20 \pm 1.36^{\mathrm{a}}$ & $181.00 \pm 3.11^{\mathrm{a}}$ & $48.60 \pm 1.03^{\mathrm{a}}$ & $93.00 \pm 1.84^{\mathrm{a}}$ & $182.80 \pm 2.06^{\mathrm{a}}$ & $50.88 \pm 0.92^{\mathrm{a}}$ & $106.78 \pm 1.95^{\mathrm{a}}$ & $189.32 \pm 3.07^{\mathrm{a}}$ \\
\hline $\mathbf{G}_{5}$ & $34.00 \pm 0.71^{\mathrm{b}}$ & $65.20 \pm 1.77^{\mathrm{b}}$ & $167.70 \pm 1.43^{\mathrm{b}}$ & $38.60 \pm 1.21^{\mathrm{b}}$ & $58.00 \pm 1.00^{\mathrm{c}}$ & $162.40 \pm 0.83^{b}$ & $28.00 \pm 0.71^{\mathrm{b}}$ & $48.20 \pm 0.86^{\mathrm{b}}$ & $155.80 \pm 1.56^{\mathrm{b}}$ \\
\hline $\mathbf{G}_{\mathbf{6}}$ & $35.00 \pm 0.71^{\mathrm{b}}$ & $67.80 \pm 1.16^{\mathrm{b}}$ & $168.80 \pm 2.27^{\mathrm{b}}$ & $38.80 \pm 1.16^{\mathrm{b}}$ & $63.40 \pm 1.08^{\mathrm{b}}$ & $167.62 \pm 0.96^{\mathrm{b}}$ & $29.40 \pm 1.03^{\mathrm{b}}$ & $49.00 \pm 2.10^{\mathrm{b}}$ & $156.16 \pm 1.79^{b}$ \\
\hline
\end{tabular}

${ }^{1}$ ALT: alanine aminotransferase; ${ }^{2}$ AST: aspartate aminotransferase and ${ }^{3}$ ALP: alkaline phosphatase.

$\mathrm{G}_{1}$ : control group (negative control); $\mathrm{G}_{2}$ : received rosemary aqueous extract (100 mg/kg BW/day) orally in drinking water for 6 weeks; $\mathrm{G}_{3}$ : received licorice aqueous extract (150 $\mathrm{mg} / \mathrm{kg} \mathrm{BW} /$ day) orally in drinking water for 6 weeks; $\mathrm{G}_{4}$ : received lead acetate $\left(0.2 \%\right.$ ) in drinking water for 6 weeks (positive control); $\mathrm{G}_{5}$ : received lead acetate in combination with the aqueous extract of rosemary $(0.2 \%)$ in drinking water for 6 weeks and $\mathrm{G}_{6}$ : received lead acetate in combination with the licorice in drinking water for 6 weeks.

Means within the same column carrying different superscript letters were significantly different at $\mathrm{p} \leq 0.05$ 


\section{Effect on protein profile}

Rats in group 2 revealed a significant increase in serum TP and globulin, while albumin and $\mathrm{A} / \mathrm{G}$ ratio didn't show a significant change in comparison to the control group. Group 3 showed a non significant change in proteinogram during different experimental periods. Rats in group 4 showed a significant reduction in $\mathrm{TP}$, albumin and globulin, while $\mathrm{A} / \mathrm{G}$ ratio showed a non significant change. A significant reduction in TP and albumin with non significant change in globulin and $\mathrm{A} / \mathrm{G}$ ratio was noticed in groups 5 and 6 at the end of the $2^{\text {nd }}$ and $4^{\text {th }}$ weeks of the experiment. However, non significant change in proteinogram was recorded at the end of the $6^{\text {th }}$ week in comparison to the control group. Rats in groups 5 and 6 revealed a significant increase in TP, albumin and globulin in comparison to group 4 during all the experimental periods.

\section{Effect on some renal function tests}

The serum creatinine and urea levels showed non significant change in groups 2 and 3 , while a significant increase was recorded in groups 4,5 and 6 when compared with the control group during the experimental periods. On the other hand, groups 5 and 6 showed a significant decrease in serum creatinine and urea levels when compared with group 4 in all experimental periods.

\section{Effect on immunoglobulins levels}

Seum IgG level showed a significant increase in rats of groups 2 and 3. It showed a significant decrease in group 4 in all experimental periods and only at the $2^{\text {nd }}$ and $4^{\text {th }}$ week post-treatment in groups 5 and 6 when compared with the control group. Serum $\operatorname{IgM}$ and $\operatorname{Ig} \mathrm{A}$ levels were significantly increased in group 2 and nonsignificantly changed in group 3 in all experimental periods when compared with the control rats. However, they revealed a significant decrease in all experimental periods in group 4 and only at the end of $2^{\text {nd }}$ and $4^{\text {th }}$ week in groups 5 and 6. The decrease in serum IgG, IgM and IgA values was more in group 4 than the others. Rats in groups 5 and 6 showed a significant increase in all immunoglobulins when compared with the group 4 during all experimental periods

\section{Effect on antioxidant activities and MDA}

Rats in groups 2 and 3 revealed a significant increase in the serum CAT and SOD activities with a significant reduction in MDA level when compared with the control group during all the experimental periods. However, the serum antioxidants activities showed a significant decrease, while MDA revealed a significant increase in all the experimental periods in rats of group 4 and only at the $2^{\text {nd }}$ and $4^{\text {th }}$ week of the experiment in groups 5and 6 when compared with the control group. In comparison with group 4, rats in groups 5 and 6 showed a significant increase in serum CAT and SOD activities with a significant decrease in MDA level during all the periods of the experiment. 
Table 2: Serum proteins' profile of albino rats at 2, 4 and 6 weeks post-treatment (Means \pm SE)

\begin{tabular}{|c|c|c|c|c|c|c|c|c|c|c|c|c|}
\hline \multirow[b]{3}{*}{ Parameters } & \multicolumn{12}{|c|}{ Times post-treatment } \\
\hline & \multicolumn{4}{|c|}{2 weeks } & \multicolumn{4}{|c|}{4 weeks } & \multicolumn{4}{|c|}{6 weeks } \\
\hline & $\begin{array}{c}\text { TP } \\
(\mathrm{g} / \mathrm{dL})^{1}\end{array}$ & $\begin{array}{c}\text { Alb } \\
(\mathrm{g} / \mathrm{dL})^{2}\end{array}$ & $\begin{array}{c}\text { Glob } \\
(\mathrm{g} / \mathrm{dL})^{3}\end{array}$ & $\begin{array}{c}\text { A/G } \\
\text { Ratio }\end{array}$ & $\begin{array}{c}\mathbf{T P} \\
(\mathbf{g} / \mathbf{d L})\end{array}$ & $\begin{array}{c}\text { Alb } \\
(\mathrm{g} / \mathrm{dL})\end{array}$ & $\begin{array}{c}\text { Glob } \\
\text { (g/dL) }\end{array}$ & $\begin{array}{l}\mathrm{A} / \mathrm{G} \\
\text { ratio }\end{array}$ & $\begin{array}{c}\text { TP ( } \\
\text { g/dL) }\end{array}$ & $\begin{array}{c}\text { Alb } \\
\text { (g/dL) }\end{array}$ & $\begin{array}{c}\text { Glob } \\
\text { (g/dL) }\end{array}$ & $\begin{array}{l}\mathrm{A} / \mathrm{G} \\
\text { ratio }\end{array}$ \\
\hline $\mathbf{G}_{1}$ & $6.50 \pm 0.10^{\mathrm{b}}$ & $3.16 \pm 0.05^{\mathrm{a}}$ & $3.34 \pm 0.05^{\mathrm{b}}$ & $0.95 \pm 0.01^{\mathrm{ab}}$ & $6.60 \pm 0.11^{\mathrm{b}}$ & $3.14 \pm 0.04^{\mathrm{a}}$ & $3.50 \pm 0,07^{\mathrm{b}}$ & $0.90 \pm 0.01$ & $6.56 \pm 0.13^{\mathrm{b}}$ & $3.12 \pm 0.07^{\mathrm{ab}}$ & $3.44 \pm 0.07^{\mathrm{b}}$ & $0.90 \pm 0.00$ \\
\hline $\mathbf{G}_{2}$ & $6.94 \pm 0.07^{\mathrm{a}}$ & $3.28 \pm 0.06^{\mathrm{a}}$ & $3.66 \pm 0.04^{\mathrm{a}}$ & $0.90 \pm 0.02^{\mathrm{b}}$ & $7.26 \pm 0.18^{\mathrm{a}}$ & $3.30 \pm 0.09^{\mathrm{a}}$ & $4.16 \pm 0.22^{\mathrm{a}}$ & $0.80 \pm 0.05$ & $7.70 \pm 0.07^{\mathrm{a}}$ & $3.36 \pm 0.07^{\mathrm{a}}$ & $4.34 \pm 0.12^{\mathrm{a}}$ & $0.78 \pm 0.03$ \\
\hline $\mathbf{G}_{3}$ & $6.56 \pm 0.11^{\mathrm{b}}$ & $3.30 \pm 0.07^{\mathrm{a}}$ & $3.26 \pm 0.05^{\mathrm{b}}$ & $1.01 \pm 0.02^{\mathrm{a}}$ & $6.46 \pm 0.14^{\mathrm{b}}$ & $3.14 \pm 0.06^{\mathrm{a}}$ & $3.32 \pm 0.08^{b}$ & $0.95 \pm 0.01$ & $6.44 \pm 0.10^{\mathrm{b}}$ & $3.04 \pm 0.05^{\mathrm{b}}$ & $3.46 \pm 0.07^{\mathrm{b}}$ & $0.88 \pm 0.01$ \\
\hline $\mathbf{G}_{4}$ & $4.14 \pm 0.11^{\mathrm{d}}$ & $2.00 \pm 0.07^{\mathrm{c}}$ & $2.14 \pm 0.07^{\mathrm{c}}$ & $0.94 \pm 0.04^{\mathrm{ab}}$ & $4.12 \pm 0.16^{\mathrm{d}}$ & $1.96 \pm 0.09^{\mathrm{d}}$ & $2.16 \pm 0.09^{c}$ & $0.91 \pm 0.04$ & $3.82 \pm 0.11^{\mathrm{c}}$ & $1.72 \pm 0.10^{\mathrm{c}}$ & $2.10 \pm 0.19^{c}$ & $0.87 \pm 0.14$ \\
\hline $\mathbf{G}_{5}$ & $5.20 \pm 0.11^{\mathrm{c}}$ & $2.06 \pm 0.05^{\mathrm{bc}}$ & $3.14 \pm 0.09^{\mathrm{b}}$ & $0.66 \pm 0.02^{\mathrm{c}}$ & $5.84 \pm 0.11^{\mathrm{c}}$ & $2.78 \pm 0.09^{b}$ & $3.06 \pm 0.11^{\mathrm{b}}$ & $0.92 \pm 0.05$ & $6.14 \pm 0.14^{\mathrm{b}}$ & $2.90 \pm 0.07^{\mathrm{b}}$ & $3.24 \pm 0.18^{\mathrm{b}}$ & $0.91 \pm 0.07$ \\
\hline $\mathbf{G}_{6}$ & $5.40 \pm 0.07^{\mathrm{c}}$ & $2.26 \pm 0.05^{\mathrm{b}}$ & $3.14 \pm 0.04^{b}$ & $0.72 \pm 0.02^{\mathrm{c}}$ & $5.48 \pm 0.10^{\mathrm{c}}$ & $2.40 \pm 0.12^{\mathrm{c}}$ & $3.08 \pm 0.06^{\mathrm{b}}$ & $0.78 \pm 0.05$ & $5.92 \pm 0.11^{\mathrm{b}}$ & $2.88 \pm 0.06^{b}$ & $3.04 \pm 0.08^{\mathrm{b}}$ & $0.95 \pm 0.03$ \\
\hline
\end{tabular}

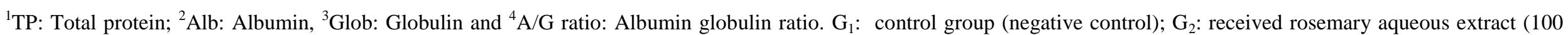
$\mathrm{mg} / \mathrm{kg} \mathrm{BW} /$ day $)$ orally in drinking water for 6 weeks; $\mathrm{G}_{3}$ : received licorice aqueous extract ( $150 \mathrm{mg} / \mathrm{kg}$ BW/day) orally in drinking water for 6 weeks; $\mathrm{G}_{4}$ : received lead acetate $(0.2 \%)$ in drinking water for 6 weeks (positive control); $\mathrm{G}_{5}$ : received lead acetate in combination with the aqueous extract of rosemary ( $0.2 \%$ ) in drinking water for 6 weeks and $\mathrm{G}_{6}$ : received lead acetate in combination with the licorice in drinking water for 6 weeks.

Means within the same column carrying different superscript letters were significantly different at $\mathrm{p} \leq 0.05$ 
Table 3: Some renal function tests of albino rats at 2, 4 and 6 weeks post-treatment (Means \pm SE)

\begin{tabular}{|c|c|c|c|c|c|c|}
\hline \multirow[b]{3}{*}{ Parameters } & \multicolumn{6}{|c|}{ Times post-treatment } \\
\hline & \multicolumn{2}{|c|}{2 weeks } & \multicolumn{2}{|c|}{4 weeks } & \multicolumn{2}{|c|}{6 weeks } \\
\hline & $\begin{array}{c}\text { Creatinine } \\
(\mathbf{m g} / \mathbf{d L})\end{array}$ & $\begin{array}{c}\text { Urea } \\
(\mathrm{mg} / \mathrm{dL}) \\
\end{array}$ & $\begin{array}{c}\text { Creatinine } \\
(\mathrm{mg} / \mathrm{dL})\end{array}$ & $\begin{array}{c}\text { Urea } \\
(\mathrm{mg} / \mathrm{dL})\end{array}$ & $\begin{array}{c}\text { Creatinine } \\
(\mathrm{mg} / \mathrm{dL})\end{array}$ & $\begin{array}{c}\text { Urea } \\
(\mathrm{mg} / \mathrm{dL})\end{array}$ \\
\hline $\mathbf{G}_{1}$ & $0.46 \pm 0.02^{\mathrm{c}}$ & $32.80 \pm 0.86^{\mathrm{d}}$ & $0.43 \pm 0.01^{\mathrm{c}}$ & $36.40 \pm 1.08^{\mathrm{c}}$ & $0.44 \pm 0.02^{\mathrm{b}}$ & $36.38 \pm 0.60^{b}$ \\
\hline $\mathbf{G}_{\mathbf{2}}$ & $0.43 \pm 0.01^{\mathrm{c}}$ & $33.80 \pm 0.86^{\mathrm{d}}$ & $0.42 \pm 0.01^{\mathrm{c}}$ & $34.20 \pm 0.82^{\mathrm{c}}$ & $0.44 \pm 0.01^{\mathrm{b}}$ & $37.34 \pm 0.35^{b}$ \\
\hline $\mathbf{G}_{3}$ & $0.44 \pm 0.02^{\mathrm{c}}$ & $33.00 \pm 0.71^{\mathrm{d}}$ & $0.45 \pm 0.01^{\mathrm{c}}$ & $35.60 \pm 0.86^{\mathrm{c}}$ & $0.46 \pm 0.01^{\mathrm{b}}$ & $36.72 \pm 0.27^{b}$ \\
\hline $\mathbf{G}_{4}$ & $1.46 \pm 0.09^{\mathrm{a}}$ & $67.00 \pm 0.71^{\mathrm{a}}$ & $1.91 \pm 0.07^{\mathrm{a}}$ & $70.80 \pm 0.86^{\mathrm{a}}$ & $2.82 \pm 0.21^{\mathrm{a}}$ & $80.60 \pm 1.08^{\mathrm{a}}$ \\
\hline $\mathbf{G}_{5}$ & $0.75 \pm 0.02^{\mathrm{b}}$ & $52.80 \pm 0.86^{\mathrm{c}}$ & $0.60 \pm 0.02^{\mathrm{b}}$ & $45.82 \pm 0.42^{b}$ & $0.50 \pm 0.01^{\mathrm{b}}$ & $38.76 \pm 0.75^{b}$ \\
\hline $\mathbf{G}_{\mathbf{6}}$ & $0.82 \pm 0.03^{\mathrm{b}}$ & $56.40 \pm 1.21^{\mathrm{b}}$ & $0.62 \pm 0.02^{\mathrm{b}}$ & $48.80 \pm 0.86^{\mathrm{b}}$ & $0.55 \pm 0.02^{\mathrm{b}}$ & $39.98 \pm 0.37^{\mathrm{b}}$ \\
\hline
\end{tabular}

$\overline{\mathrm{G}_{1}}$ : control group (negative control); $\mathrm{G}_{2}$ : received rosemary aqueous extract (100 $\mathrm{mg} / \mathrm{kg} \mathrm{BW} /$ day) orally in drinking water for 6 weeks; $\mathrm{G}_{3}$ : received licorice aqueous extract (150 $\mathrm{mg} / \mathrm{kg} \mathrm{BW} /$ day) orally in drinking water for 6 weeks; $\mathrm{G}_{4}$ : received lead acetate $\left(0.2 \%\right.$ ) in drinking water for 6 weeks (positive control); $\mathrm{G}_{5}$ : received lead acetate in combination with the aqueous extract of rosemary $(0.2 \%)$ in drinking water for 6 weeks and $\mathrm{G}_{6}$ : received lead acetate in combination with the licorice in drinking water for 6 weeks.

Means within the same column carrying different superscript letters were significantly different at $\mathrm{p} \leq 0.05$. 
Table 4: Immunoglobulins (mg/dL) of albino rats at 2, 4 and 6 weeks post-treatment (Means \pm SE)

\begin{tabular}{|c|c|c|c|c|c|c|c|c|c|}
\hline \multirow{2}{*}{ Parameters } & \multicolumn{3}{|c|}{2 weeks } & \multicolumn{3}{|c|}{$\begin{array}{c}\text { Times post-treatment } \\
4 \text { weeks }\end{array}$} & \multicolumn{3}{|c|}{6 weeks } \\
\hline & IgG & IgM & IgA & IgG & IgM & IgA & IgG & IgM & IgA \\
\hline $\mathbf{G}_{1}$ & $744 \pm 4.30^{\mathrm{b}}$ & $168 \pm 2.81^{\mathrm{b}}$ & $52.40 \pm 1.63^{\mathrm{b}}$ & $744.0 \pm 2.98^{\mathrm{b}}$ & $170.40 \pm 1.89^{\mathrm{b}}$ & $54.00 \pm 1.95^{\mathrm{b}}$ & $746.00 \pm 3.05^{\mathrm{b}}$ & $168.60 \pm 1.60^{\mathrm{b}}$ & $52.20 \pm 1.66^{\mathrm{l}}$ \\
\hline $\mathbf{G}_{2}$ & $804 \pm 9.27^{\mathrm{a}}$ & $191 \pm 2.92^{\mathrm{a}}$ & $61.40 \pm 1.21^{\mathrm{a}}$ & $828.0 \pm 14.63^{\mathrm{a}}$ & $204.20 \pm 3.97^{\mathrm{a}}$ & $65.80 \pm 1.88^{\mathrm{a}}$ & $819.8 \pm 15.64^{\mathrm{a}}$ & $209.00 \pm 6.40^{\mathrm{a}}$ & $62.00 \pm 1.00$ \\
\hline $\mathbf{G}_{3}$ & $795 \pm 5.70^{\mathrm{a}}$ & $172 \pm 2.50^{\mathrm{b}}$ & $50.00 \pm 1.00^{\mathrm{b}}$ & $802.60 \pm 6.69^{a}$ & $175.00 \pm 2.77^{\mathrm{b}}$ & $54.20 \pm 1.66^{\mathrm{b}}$ & $815.00 \pm 7.07^{\mathrm{a}}$ & $169.00 \pm 2.35^{\mathrm{b}}$ & $52.80 \pm 1.85^{\mathrm{l}}$ \\
\hline $\mathbf{G}_{\mathbf{4}}$ & $528 \pm 11.58^{\mathrm{e}}$ & $127 \pm 2.50^{\mathrm{d}}$ & $30.20 \pm 1.77^{\mathrm{d}}$ & $505.0 \pm 12.25^{\mathrm{d}}$ & $120.20 \pm 1.77^{\mathrm{d}}$ & $28.80 \pm 0.80^{\mathrm{d}}$ & $411.20 \pm 11.70^{\mathrm{c}}$ & $115.20 \pm 2.15^{\mathrm{c}}$ & $24.80 \pm 1.77^{\circ}$ \\
\hline $\mathbf{G}_{5}$ & $654 \pm 9.27^{\mathrm{c}}$ & $145 \pm 1.03^{c}$ & $41.60 \pm 1.21^{\mathrm{c}}$ & $695.20 \pm 5.16^{\mathrm{c}}$ & $155.00 \pm 1.70^{\mathrm{c}}$ & $45.40 \pm 0.51^{\mathrm{c}}$ & $728.60 \pm 4.63^{b}$ & $158.00 \pm 1.79^{\mathrm{b}}$ & $51.60 \pm 1.63$ \\
\hline $\mathbf{G}_{6}$ & $618 \pm 12.41^{\mathrm{d}}$ & $142 \pm 1.50^{c}$ & $39.80 \pm 1.43^{\mathrm{c}}$ & $676.80 \pm 2.08^{c}$ & $151.00 \pm 1.14^{\mathrm{c}}$ & $42.20 \pm 0.73^{\mathrm{c}}$ & $732.00 \pm 4.64^{b}$ & $157.00 \pm 1.73^{\mathrm{b}}$ & $50.20 \pm 1.98^{\mathrm{t}}$ \\
\hline
\end{tabular}

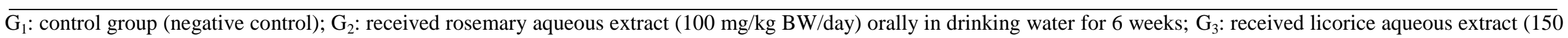

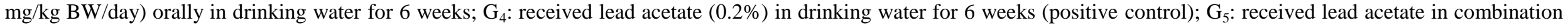
with the aqueous extract of rosemary $(0.2 \%)$ in drinking water for 6 weeks and $\mathrm{G}_{6}$ : received lead acetate in combination with the licorice in drinking water for 6 weeks.

Means within the same column carrying different superscript letters were significantly different at $\mathrm{p} \leq 0.05$. 
Table 5: Some antioxidant enzymes activities and malondialdhyde in serum of albino rats at 2, 4 and 6 weeks post-treatment (Means \pm SE)

\begin{tabular}{|c|c|c|c|c|c|c|c|c|c|}
\hline \multirow[b]{2}{*}{ Parameters } & \multicolumn{9}{|c|}{$\begin{array}{c}\text { Times post-treatment } \\
4 \text { weeks }\end{array}$} \\
\hline & $\begin{array}{c}\text { CAT } \\
(\mathbf{U} / \mathbf{m L})^{1}\end{array}$ & $\operatorname{SOD}(\mathrm{U} / \mathrm{mL})^{2}$ & $\operatorname{MDA}(\mathrm{mmol} / \mathrm{L})^{3}$ & CAT $(\mathbf{U} / \mathbf{m L})$ & $\operatorname{SOD}(\mathrm{U} / \mathrm{mL})$ & MDA (mmol/L) & CAT $(\mathrm{U} / \mathrm{mL})$ & SOD $(\mathrm{U} / \mathrm{mL})$ & MDA (mmol/L) \\
\hline $\mathbf{G}_{1}$ & $60.40 \pm 0.93^{\mathrm{b}}$ & $91.40 \pm 0.93^{\mathrm{c}}$ & $8.34 \pm 0.18^{\mathrm{c}}$ & $63.50 \pm 1.23^{\mathrm{b}}$ & $91.98 \pm 1.13^{\mathrm{c}}$ & $8.64 \pm 0.10^{c}$ & $62.38 \pm 1.46^{\mathrm{c}}$ & $91.00 \pm 0.81^{\mathrm{c}}$ & $8.90 \pm 0.15^{\mathrm{b}}$ \\
\hline $\mathbf{G}_{2}$ & $76.40 \pm 1.81^{\mathrm{a}}$ & $116.2 \pm 1.77^{\mathrm{a}}$ & $6.64 \pm .0 .09^{\mathrm{e}}$ & $79.58 \pm 0.68^{\mathrm{a}}$ & $117.7 \pm 0.88^{\mathrm{a}}$ & $6.52 \pm 0.11^{\mathrm{e}}$ & $86.70 \pm 1.12^{\mathrm{a}}$ & $120.0 \pm 1.71^{\mathrm{a}}$ & $5.92 \pm 0.09^{\mathrm{d}}$ \\
\hline $\mathbf{G}_{3}$ & $74.00 \pm 1.22^{\mathrm{a}}$ & $105.6 \pm 1.23^{\mathrm{b}}$ & $7.40 \pm 0.13^{\mathrm{d}}$ & $76.72 \pm 0.70^{\mathrm{a}}$ & $108.1 \pm .55^{\mathrm{b}}$ & $7.10 \pm 0.22^{\mathrm{d}}$ & $79.32 \pm 0.69^{\mathrm{b}}$ & $115.4 \pm 1.16^{\mathrm{b}}$ & $7.80 \pm 11.30^{\mathrm{c}}$ \\
\hline $\mathbf{G}_{4}$ & $46.40 \pm 0.93^{\mathrm{d}}$ & $74.80 \pm 1.36^{\mathrm{f}}$ & $11.94 \pm 0.26^{\mathrm{a}}$ & $39.52 \pm 0.63^{\mathrm{d}}$ & $70.20 \pm 0.86^{\mathrm{e}}$ & $12.62 \pm 0.20^{\mathrm{a}}$ & $33.70 \pm 1.17^{\mathrm{d}}$ & $61.44 \pm 1.06^{\mathrm{d}}$ & $13.14 \pm 0.28^{\mathrm{a}}$ \\
\hline $\mathbf{G}_{5}$ & $54.40 \pm 1.50^{\mathrm{c}}$ & $86.00 \pm 1.14^{\mathrm{d}}$ & $10.50 \pm 0.10^{\mathrm{b}}$ & $56.02 \pm 1.59^{\mathrm{c}}$ & $84.94 \pm 1.83^{\mathrm{d}}$ & $9.88 \pm 0.09^{\mathrm{b}}$ & $61.96 \pm 0.96^{\mathrm{c}}$ & $90.44 \pm 1.17^{\mathrm{c}}$ & $9.04 \pm 0.23^{\mathrm{b}}$ \\
\hline $\mathbf{G}_{6}$ & $52.80 \pm 1.46^{\mathrm{c}}$ & $81.00 \pm 0.71^{\mathrm{e}}$ & $10.68 \pm 0.21^{b}$ & $55.56 \pm 0.63^{\mathrm{c}}$ & $83.28 \pm 1.17^{\mathrm{d}}$ & $10.18 \pm 0.18^{b}$ & $60.44 \pm 1.42^{c}$ & $88.68 \pm 1.35^{\mathrm{c}}$ & $9.64 \pm 0.25^{\mathrm{b}}$ \\
\hline
\end{tabular}

${ }^{1}$ CAT: catalase activities; ${ }^{2}$ SOD: superoxide dismutase activities and ${ }^{3}$ MDA: malondialdhyde. $\mathrm{G}_{1}$ : control group (negative control); $\mathrm{G}_{2}:$ received rosemary aqueous extract (100 $\mathrm{mg} / \mathrm{kg}$ BW/day) orally in drinking water for 6 weeks; $\mathrm{G}_{3}$ : received licorice aqueous extract ( $150 \mathrm{mg} / \mathrm{kg}$ BW/day) orally in drinking water for 6 weeks; $\mathrm{G}_{4}$ : received lead acetate $(0.2 \%)$ in drinking water for 6 weeks (positive control); $\mathrm{G}_{5}$ : received lead acetate in combination with the aqueous extract of rosemary $(0.2 \%)$ in drinking water for 6 weeks and $\mathrm{G}_{6}$ : received lead acetate in combination with the licorice in drinking water for 6 weeks.

Means within the same column carrying different superscript letters were significantly different at $\mathrm{p} \leq 0.05$. 


\section{Discussion}

Oxidative stress is one of the major mechanisms of lead toxicity. Medicinal plants with antioxidant effects are excellent choice to protect against oxidative stress with least side effects. Rosemary and licorice have an antioxidant action. Rats received rosemary or licorice alone appeared healthy without mortalities. This may be attributed to the useful role of rosemary in controlling nutrients uptake through GIT and the immunomodulatory effect of rosemary [24] and licorice [25] that improved the health status of rats. On the other hand, inappetence, general weakness and weight loss with high mortality rate were observed in the lead group may be attributed to the direct effect of lead on the GIT initiating deficient absorption of nutrients or on protein synthesis [26]. The severity of clinical signs was improved in groups 5and 6, which agreed with earlier studies $[24,25]$.

Administration of rosemary or licorice to normal rats didn't induce significant changes in liver or kidney functions except an increase in serum total protein and globulin levels in rosemary group. This may be due to that rosemary has a more beneficial immuneimproving effect than licorice and both rosemary and licorice have no deleterious effects on liver and kidney. These results are in agreement with others who reported that administration of rosemary extract [27] or licorice [28] didn't induce any change in serum ALT, AST and ALP activities.

Activities of AST and ALT are most commonly used as biochemical markers for monitoring chemically induced liver damage. In the present study, administration of lead $\left(\mathrm{G}_{4}\right)$ caused a significant increase in the levels of liver enzymes (ALT, AST and ALP activities). These results might be due to organ failure or damage, as the excessive generation of ROS as well as depletion of the antioxidant reserves, cause accumulation of ROS in hepatocytes leading to hepatotoxicity and liberation of ALT from damaged hepatocytes into the systemic circulation [29]. Similar changes in the values of ALT and AST were associated with lead acetate intoxication in rats $[24,30]$. On the other hand, the increases in the previous enzymes activities were significantly suppressed by administration of rosemary $\left(\mathrm{G}_{5}\right)$ or licorice extracts $\left(\mathrm{G}_{6}\right)$ at all experimental periods when compared with the positive control $\left(\mathrm{G}_{4}\right)$. Treatment with rosemary or licorice of lead-induced oxidative stress rats were able to alleviate hepatic damage by lowering their biomarkers through scavenging the free radicals and terminating the membrane LPO by improving cellular antioxidant defense system. Glicyrrhizic acid showed hepatoprotective effect through preventing changes in the cell membrane permeability and increasing the survival rate of hepatocytes. These outcomes agreed with previous results [31,32].

Rosemary treated rats $\left(\mathrm{G}_{2}\right)$ revealed a significant increase in serum TP and globulins and this agreed with others [33], who reported that rosemary extract had a beneficial effect on immunity by developing and protecting cells and inhibiting non-enzymatic oxidation. On the other hand, rats received licorice $\left(\mathrm{G}_{3}\right)$ showed non-significant changes in TP, albumin, globulin and $\mathrm{A} / \mathrm{G}$ ratio during all the experimental periods, which is comparable to the findings of Jagadeeswaran and Selvasubramanian [34]. Lead-treated rats $\left(\mathrm{G}_{4}\right)$ showed a significant decrease in all proteinogram which may be due to the catabolic effects of lead [35] or decrease the number of hepatocytes that may cause a reduction of hepatic capacity to synthesize protein [29]. Similar changes in serum TP and albumin were previously obtained by ElTantawy [36]. But, the restoration of TP and albumin levels after the administration of rosemary $\left(\mathrm{G}_{5}\right)$ or licorice extracts $\left(\mathrm{G}_{6}\right)$ confirmed the hepatoprotective nature of both extracts and agreed with those obtained in rat of lead induced toxicity that treated with rosemary or licorice root extract $[9,28]$.

Administration of rosemary $\left(\mathrm{G}_{2}\right)$ or licorice alone $\left(\mathrm{G}_{3}\right)$ showed no significant change in serum urea and creatinine levels. This indicated that both plants are safe and had no deleterious effect on kidney. On the other hand, chronic lead exposure $\left(\mathrm{G}_{4}\right)$ induced a significant increase in serum urea and creatinine in all experimental periods. This elevation was reflected the state of glomerular filtration and indicated kidney damage. Leadinduced renal dysfunction may be associated 
with the attenuation of cell membrane integrity with cell damage or the effect of excessive production of ROS. Also, decreased renal perfusion may be due to the metabolic disorders caused by lead [35]. Combination of lead with rosemary $\left(\mathrm{G}_{5}\right)$ or licorice $\left(\mathrm{G}_{6}\right)$ improved the kidney functions in a duration dependent effect as creatinine and urea levels returned to the normal level by the $6^{\text {th }}$ week of the experiment. These results were in harmony with others [25,37].

The current results showed that rosemary $\left(\mathrm{G}_{2}\right)$ increased all types of immunoglobulins, while licorice $\left(\mathrm{G}_{3}\right)$ increased only serum $\mathrm{IgG}$. The increase in the globulin fractions indicated the effective role of rosemary in increasing immunity due to its role in developing and protecting cells and inhibiting nonenzymatic oxidation [38]. Conversely, lead acetate administration $\left(\mathrm{G}_{4}\right)$ caused a significant decrease in serum immunoglobulins (IgG, IgM and $\operatorname{Ig} \mathrm{A}$ ) during the different experimental periods. These results indicated that lead had a deleterious effect on humeral immunity. The effect of lead was modulated by the addition of rosemary $\left(\mathrm{G}_{5}\right)$ or licorice $\left(\mathrm{G}_{6}\right)$. These results indicated that rosemary or licorice extracts improved the immunoglobulins state and rosemary was more potent than licorice as an immunomodulating agent [38].

Oxidative stress is induced by excessive production of superoxides, hydrogen peroxides and hydroxyl radicals and/or by insufficient antioxidative resistance [39]. Regarding the antioxidant activities, our study revealed that rosemary and licorice extracts have antioxidative properties that appeared as a significant increase in serum CAT and SOD levels with a significant decrease in MAD $\left(\mathrm{G}_{3,4}\right)$. The powerful antioxidant activity of rosemary may be due to the presence of phenolic compounds [40] and that of licorice to its content of flavonoids [41]. However, rats given lead acetate alone $\left(\mathrm{G}_{4}\right)$ affected the antioxidant activities by a significant reduction in CAT and SOD with a significant increase in MDA due to lipid peroxidation in a duration dependent effect. From our opinion, this may be related to the effect of lead toxicity that increased the oxidative stress with excessive production of free radicals and exhausted the antioxidant defense system leading to decrease
CAT and SOD with increased lipid peroxidation (MDA). Lead toxicity leads to free radical damage by two pathways; the first is the generation of reactive oxygen species (ROS) including hydroperoxides and hydrogen peroxides evaluated by MDA levels as the final product of lipid peroxidation, while the second is the direct depletion of antioxidant reserves $[3,4]$. These results agreed with other previously reported findings $[11,30,36,37]$. Addition of rosemary $\left(\mathrm{G}_{5}\right)$ or licorice $\left(\mathrm{G}_{6}\right)$ extracts to rats exposure to lead, improved the antioxidant activities that returned to the normal level after the $6^{\text {th }}$ week from the beginning of the experiment, which was evidenced by a significant increase in CAT and SOD levels with a significant decrease in MAD level when compared with lead received group. This may be due to the active natural components present in rosemary and licorice, which have antioxidant activities through the elimination of free radicals and subsequently prevent the cellular destruction $[41,42]$. Similar results concerning the increase of CAT and SOD with significant decrease of MDA levels were obtained in rabbits received rosemary in combination with lead acetate [33] and in rats administered licorice with lead acetate [30].

\section{Conclusion}

From these obtained findings, we can conclude that rosemary and licorice extracts have a protective role in alleviating the harmful effects of lead on the hepato-renal functions, immunity and antioxidants activities.

\section{Conflict of interest}

The authors declare that they have no conflict of interest.

\section{References}

[1] Sies, H. (1997): Oxidative stress: oxidants and antioxidants. Exp Physiol, 82(2): 291295.

[2] Sultana, S.; Ripa, F.A. and Hamid, K. (2010): Comparative antioxidant activity study of some commonly used spices in Bangladesh. Pak J Biol Sci, 13(7): 340343.

[3] Neal, R.; Copper, K.; Gurer, H. and Ercal, N. (1998): Effects of N-acetyl cysteine and 2, 3- 
dimercaptosuccinic acid on lead induced oxidative stress in rat lenses. Toxicology, 130: 167-174.

[4] Flora, S.; Pande, M.; Kannan, G. and Mehta, A. (2004): Lead induced oxidative stress and its recovery following coadminstration of melatonin or $\mathrm{N}$ acetylcysteine during chelation with succimer in male rats. Cell Mol Biol, Online, 543-551.

[5] Backleh, M.; Leupold, G. and Parlar, H. (2003): Rapid quantitative enrichment of carnosic acid from rosemary (Rosmarinus officinalis L.) by isoelectric focused adsorptive bubble chromatography. J Agric Food Chem, 51(5): 1297-1301.

[6] Michaelis, M.; Geiler, J.; Naczk, P.; Sithisarn, P.; Leutz, A.; Doerr, H.W. and Cinatl, J.Jr. (2011) : Glycyrrhizin exerts antioxidative effects in H5N1 influenza A virus-infected cells and inhibits virus replication and pro-inflammatory gene expression. PLoS One, 6(5): e19705.

[7] Haloui, M.; Louedec, L.; Michel, J.B. and Lyoussi, B. (2000): Experimental diuretic effects of Rosmarinus officinalis and Centaurium erythraea. J Ethnopharmacol, 71(3): 465-472.

[8] Tian, M.; Yan, H. and Row, K.H. (2008): Extraction of glycyrrhizic acid and glabridin from licorice. Int J Mol Sci, 9(4): 571-577.

[9] Al-Attar, A.M. and Shawush, N.A. (2014): Physiological investigations on the effect of olive and rosemary leaves extracts in male rats exposed to thioacetamide. Saudi J Biol Sci, 21(5): 473-480.

[10] Huo, H.Z.; Wang, B.; Liang, Y.K.; Bao, Y.Y. and Gu, Y. (2011): Hepatoprotective and antioxidant effects of licorice extract against $\mathrm{CCl}(4)$-induced oxidative damage in rats. Int $\mathrm{J}$ Mol Sci, 12(10): 6529-6543.

[11] Saxena, G. and Flora, S. (2004): Leadinduced oxidative stress and hematological alterations and their response to combined administration of calcium disodium EDTA with a thiolchelator in rats. $\mathrm{J}$ Biochem Mol Toxicol, 18(4): 221-233.
[12] Reitman, S. and Frankel, S. (1957): A colorimetric method for the determination of serum glutamic oxalacetic and glutamic pyruvic transaminases. Am J Clin Pathol, 28(1): 56-63.

[13] Seligman, A.M.; Chauncey, H.H.; Nachlas, M.M.; Manheimer, L.H. and Ravin, H.A. (1951): The colorimetric determination of phosphatases in human serum. J BiolChem, 190(1): 7-15.

[14] Henry, J.C. (1964): The basic groups of serum proteins (nbt) and atherosclerosis: Clinical Application. J Med Lyon, 45: 1537-1543.

[15] Doumas, B.T.; Watson, W.A. and Biggs, H.G. (1971): Albumin standards and the measurement of serum albumin with bromcresol green. Clin Chim Acta, 31(1): 87-96.

[16] Doumas, B. and Biggs, H. (1972): Determination of serum albumin. Standard methods of clinical chemistry, 7: $175-188$.

[17] Mancini, G.; Carbonara, A.O. and Heremans, J.F. (1965): Immunochemical quantitation of antigens by single radial immunodiffusion. Immunochem, 2: 235254.

[18] Patton, C. and Crouch, S. (1977): Spectrophotometric and kinetics investigation of the Berthelot reaction for the determination of ammonia. Anal Chem, 49: 464-468.

[19] Jaffe, M. (1986): Quantitative colorimetric determination of creatinine in serum or urine. Z Physiol Chem, 10: 391-39.

[20] Aebi, H. (1984): Catalase in vitro. Methods Enzymol, 105: 121-126.

[21] Nishikimi, M.; Rao, N.A. and Yagi, K. (1972): The occurrence of superoxide anion in the reaction of reduced phenazine methosulfate and molecular oxygen. Biochem Biophys Res Commun 46: 849-54.

[22] Valenzuela, A. (1991): The biological significance of malondialdehyde determinayion in the assessment of tissue oxidative stress. Life Sci, 48(4): 301-309. 
[23] Platt, R.W. (1998): ANOVA, t tests, and linear regression. Inj Prev, 4(1): 52-53.

[24] Abdel-Wahhab, K.G.; El-Shamy, K.A.; El-Beih, N.A.; Morcy, F.A. and Mannaa, F.A.E. (2011): Protective effect of a natural herb (Rosmarinus officinalis) against hepatotoxicity in male albino rats. Comunicata Scientiae, 2(1): 9-17.

[25] Abd El-Ghffar, E.A. (2016): Ameliorative effect of glabridin, a main component of Glycyrrhiza glabra L. roots in streptozotocin induced Type 1 diabetes in male albino rats. Indian journal of traditional knowledge, 15(4): 570-579.

[26] Gargouri, M.; Hamed, H.; Akrouti, A.; Magné, C.; Ksouri, R. and El Feki, A. (2017): Immunomodulatory and antioxidant protective effect of Sarcocornia perennis L. (swampfire) in lead intoxicated rat. Toxicology Mechanisms and Methods, 27: 697-706.

[27] Botsoglou, N.; Taitzoglou, I.; Zervos, I.; Botsoglou, E.; Tsantarliotou, M. and Chatzopoulou, P.S. (2010): Potential of long-term dietary administration of rosemary in improving the antioxidant status of rat tissues following carbon tetrachloride intoxication. Food Chem Toxicol, 48(3): 944-950.

[28] Hussein, R.S. and AbilAzeez, S.S. (2016): Effects of Glycyrrhiza glabra root extract on some physiological parameters in albino male rats treatment with lead acetate. Tikrit Journal of Pure Science, 21(3): 1813-1662.

[29] Kaneko, J.J. (1997): Porphyrins and the porphyriasis. In:Kaneko JJ, Harvey JJ W, Bruss M L, eds. Clinical Biochemistry of Domestic animals. $5^{\text {th }}$ edition. San Diego. P: 205-221.

[30] Rahman, S. and Sultana, S. (2006): Chemopreventive activity of glycyrrhizin on lead acetate mediated hepatic oxidative stress and its hyperproliferative activity in Wistar rats. ChemicoBiological Interactions, 160(1): 61-69.

[31] Botsoglou, N.; Taitzoglou, I.; Zervos, I.; Botsoglou, E.; Tsantarliotou, M. and Chatzopoulou, P.S. (2010): Potential of long-term dietary administration of rosemary in improving the antioxidant status of rat tissues following carbon tetrachloride intoxication. Food Chem Toxicol, 48(3): 944-950.

[32] Al-Qarawi, A.A.; Abdel-Rahman, H.A. and El-Mougy, S.A. (2001): Hepatoprotective activity of licorice in rat liver injury models. Journal of Herbs, Spices and Medicinal Plants, 8(1): 7-14.

[33] Ghazalah, A. and Ali, A. (2008): Rosemary leaves as a dietary supplement for growth in broiler chickens. Int J Poult Sci, 7(3): 234-239.

[34] Jagadeeswaran, A. and Selvasubramanian, S. (2014): Effect of supplementation of licorice root (Glycyrrhiza Glabra L.) extracts on immune status in commercial broilers.International Journal of Advanced Veterinary Science and Technology, 3(1): 88-92.

[35] Abd El Rahiem, A.; Yassin, M.M.; Nahed, M. and Rokaya, M. (2007): Blood, serum glucose and renal parameters in lead-loaded albino rats and treatment with some chelating agents and natural oils. Turk J Biol, 31: 25-34.

[36] El-Tantawy, W.H. (2016): Antioxidant effects of Spirulina supplement against lead acetate-induced hepatic injury in rats. Journal of traditional and complementary medicine, 6(4): 327-331.

[37] Mohamed, W.A.M.; Abd-Elhakim, Y.M. and Farouk, S.M. (2016): Protective effects of ethanolic extract of rosemary against lead-induced hepato-renal damage in rabbits. Exp Toxicol Pathol, 68(8): 451-461.

[38] Elnaggar, A.Sh.; Abdel-Latif, M.A.; ElKelawy, M.I. and Abdel Hamid, H.S. (2016): Productive, physiological and immunological effect of rosemary leaves meal (Rosemarinus officinalis) supplementing to broiler diet. Egyptian Poultry Science Journal, 36(3): 859-873.

[39] Macdonald, J.; Galley, H.F. and Webster, N.R. (2003): Oxidative stress and gene expression in sepsis. Brit $\mathrm{J}$ Anaesth, 90(2): 221-32. 
[40] Al-Kassie, G.A.; Abd-Al-Jaleel, R.A. and Mohseen, A.M. (2011): The effect of a mixture of anise and rosemary on broiler performance. Agric Biol J N Am, 2(9): 1279-1282.

[41] Ju, H.S.; Li, X.J.; Zhao, B.L.; Han, Z.W. and Xin, W.J. (1989): Effects of glycyrrhiza flavonoid on lipid peroxidation and active oxygen radicals. Yao Xue Xue Bao, 24(11): 807-812.

[42] Rashwan, N.M. and Anfenan, M.L.K. (2012): Free Radical Scavenger Effects of Licorice on the Experimental Rats. Journal of Applied Sciences Research, 8(8): 4704-4710.

\section{الملخص العربي المردي \\ دراسات بيوكيميائية على إكليل الجبل وعرق السوس في الجرذان المصابة بالإجهاد التأكسدي المستحدث بالرصاص المباص

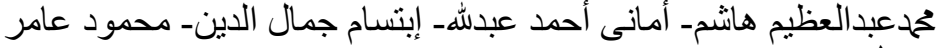

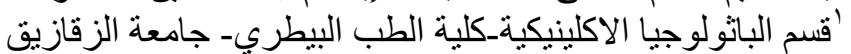

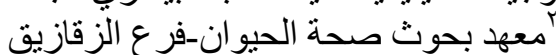

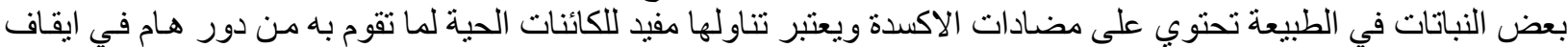

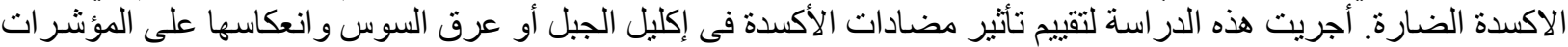

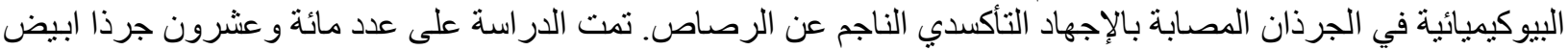

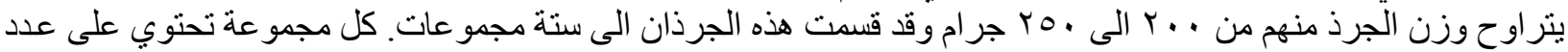

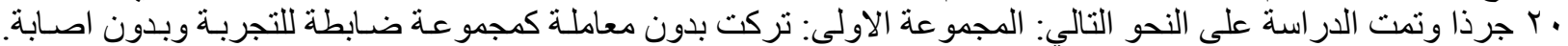

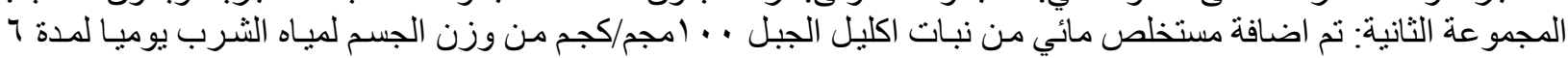

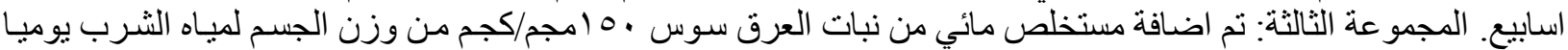

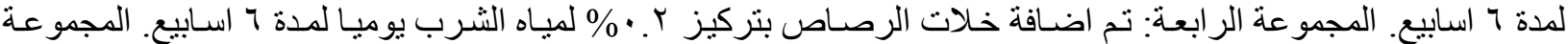

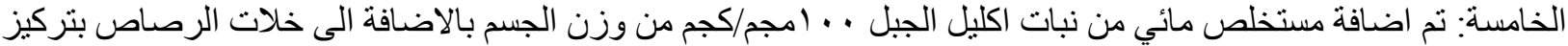

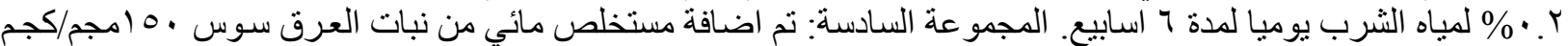

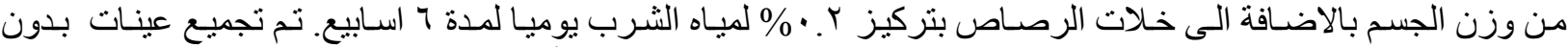

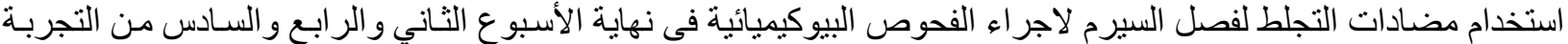

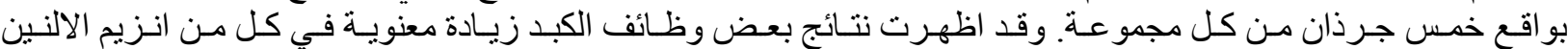

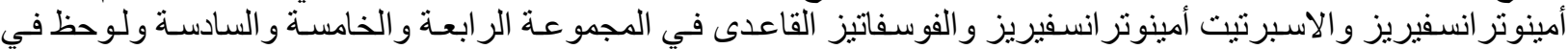

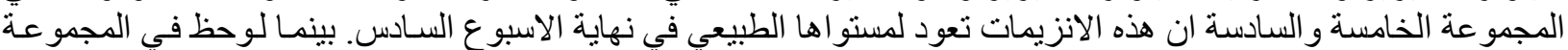

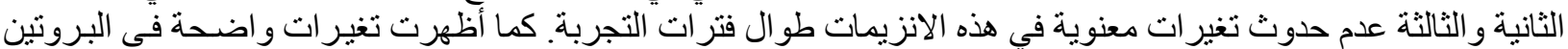

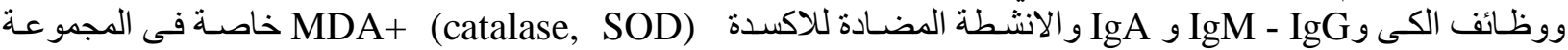

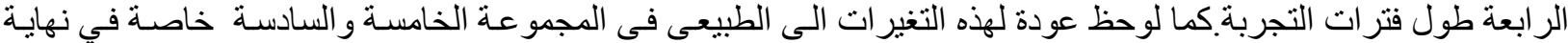

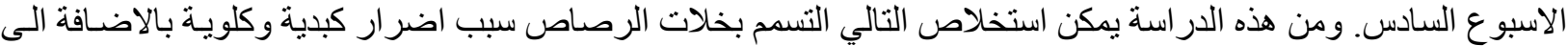

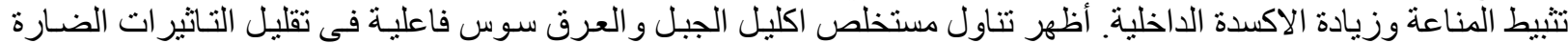

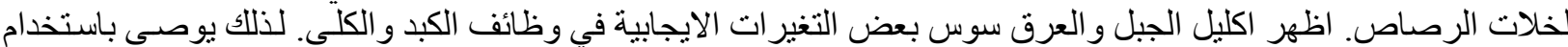
كلا النباتين كمضادات طبيعية للاكسدة وخاصة الريل الكيل الجبل. 